\title{
A Review of Emerging Health Risks with 3-MCPD Processing Contaminant in Refined Edible Oils
}

\author{
Rania I.M. Almoselhy* \\ Oils and Fats Research Department, Food Technology Research Institute, Agricultural Research \\ Center, Giza, Egypt
}

*Corresponding author: Rania I.M. Almoselhy, Oils and Fats Research Department, Food Technology Research Institute, Agricultural Research Center, Giza, Egypt, Email: rania_ almoselhy@outlook.com

\section{Mini Review}

Volume 6 Issue 3

Received Date: July 07, 2021

Published Date: August 04, 2021

DOI: 10.23880 /oajmb-16000202

\section{Abstract}

Processing contaminants are chemical substances that have not been intentionally added to edible oils or food. These substances may be present in edible oils and food as a result of the various stages of its production, processing, transport or environmental contamination and may pose a risk to animal and human health. Processing methods include fermentation, smoking, drying, refining and high-temperature cooking. Many foods must be cooked to actually be edible and digestible. It also makes them tastier. However, baking, frying, grilling or barbecuing, either at home or in manufacturing, can have undesired consequences. Besides the loss of some nutrients like vitamins, potentially harmful by-products can develop too. 3-Monochloropropanediol (3-MCPD) is an organic chemical compound, one of the heat- and process-induced food contaminants, belonging to a group called chloropropanols and is considered as the most toxic processing contaminant emerging during thermal treatments in refining of edible oils. The aim of this review was to provide an overview of current knowledge regarding 3-MCPD in edible oils for further research, in order to reduce its contents in consumed foodstuffs.

Keywords: 3-MCPD; Health Risks; Edible Oils; Processing Contaminants

Abbreviations: 3-MCPD: 3-Monochloropropanediol; TAG: Triacylglycerol; UV: ultraviolet; FT-IR: Fourier transform infrared; EC: European Commission; SCF: Scientific Committee on Food; BW: body weight; TDI: tolerable daily intake; JECFA: Joint WHO/FAO Expert Committee on Food Additives; EFSA: European Food Safety Authority; IARC: International Agency for Research on Cancer; GC-MS/ MS: gas chromatography tandem triple quadrupole mass spectrometry; IS: internal standard.

\section{Introduction}

\section{Emergence of 3-MCPD in Refined Edible Oils}

Refining of edible oils at a high temperature generates by-products such as 3-monochloropropanediol (3-MCPD) which is the most toxic food contaminant formed during thermal processing of refined edible oils [1,2]. 3-MCPD exists either in free form, or in bound form called 3-MCPD esters in different foodstuffs that has passed through cooking processes using cooking oil. In order to produce safe edible oils, usage of new materials and methods in refining process are explored, and the effects of by-products generated during this process on human body are closely monitored [3]. Deodorization is a key step during oil refining for overall oil quality, especially the deodorization temperature is the direct and critical parameter [4]. The UK Committee on Carcinogenicity of Chemicals in Food, Consumer Products and the Environment [5] has considered the carcinogenicity of 3-MCPD and its fatty acid esters. European Commission [6], the regulatory arm of the European Union, namely the European Commission (EC) Scientific Committee on Food (SCF), adopted the tolerable daily intake (TDI) of $2 \mu \mathrm{g} /$ kg body weight (bw) for 3-MCPD. Furthermore, The Joint 


\section{Open Access Journal of Microbiology \& Biotechnology}

WHO/FAO Expert Committee on Food Additives (JECFA) also recommended a provisional maximum TDI of $2 \mu \mathrm{g} / \mathrm{kg}$ bw for 3-MCPD [7,8]. In March 2016, the European Food Safety Authority (EFSA) issued an extensive report warning about the possible health consequences of contaminants created during the processing of edible oils $[9,10]$. EFSA specifically identified 3-MCPD, which was classified as a possible human carcinogen by International Agency for Research on Cancer (IARC) and documented in IARC Monographs [11]. Finally, there is a growing concern associated with release of bound 3-MCPD into its free form that results in bioavailability and absorption of 3-MCPD into human body fluids and tissues, e.g. human breast milk, which requires additional studies [12-14].

\section{Health Risks of 3-MCPD}

Kidney is one of the primary target organs for 3-MCPD [15] with induced renal injury [16], toxicity in kidney, lung, testis, and heart [17-19], immunosuppressive activity [20], toxic effects on male reproduction [21] and is regarded as a rat carcinogen inducing testicular lesions, Leydig-cell and mammary gland tumors in males and kidney tumors in both genders [22,23]. Combination of histopathological examination, clinical chemistry and metabolomics analyses resulted in systematic comprehensive assessment of the long-term toxicity of 3-MCPD, where renal tubular hyaline cast accumulation with epithelium cell degeneration and potential kidney toxicity were major histopathological changes with thin appearance and subdued behavior accompanied by decreases in bw. Microscopy revealed tubular basophilia in kidneys, exfoliated degenerative germ cells in the lumen of the seminiferous tubule of testes, vacuolation in the brain, axonal degeneration of sciatic nerve and cardiomyopathy $[24,25]$.

\section{Determinaton of 3-MCPD in Refined Edible Oils}

Almoselhy, et al. [26,27] recently carried out an investigation of 3-MCPD in some edible oils using optimized recent updated and validated enhanced swift analytical indirect method for determining 3-MCPD in consumed edible oils (palm, palm olein, extra virgin olive, corn, sunflower, soybean, olive pomace) and blend of $5 \%$ sunflower oil with extra virgin olive oil, using selective and sensitive gas chromatography tandem triple quadrupole mass spectrometry (GC-MS/MS) employing deuterated 3-MCPD (3-MCPD-d5) as internal standard (IS) during the entire analytical procedure to obtain precise and accurate results. The occurrence and variation of 3-MCPD contents among the studied oils were found in different levels ranged from 93.1 $\mu \mathrm{g} / \mathrm{kg}$ to $5634.1 \mu \mathrm{g} / \mathrm{kg}$ oil samples, with maximum value assigned for palm oil $(5634.1 \mu \mathrm{g} / \mathrm{kg})$ followed by palm olein (5576.8 $\mu \mathrm{g} / \mathrm{kg})$, corn oil (2447 $\mu \mathrm{g} / \mathrm{kg})$, sunflower oil (1817.3 $\mu \mathrm{g} / \mathrm{kg})$, soybean oil $(1486.1 \mu \mathrm{g} / \mathrm{kg})$, olive pomace oil (572.5 $\mu \mathrm{g} / \mathrm{kg}$ ), blend of $5 \%$ sunflower oil with extra virgin olive oil $(210 \mu \mathrm{g} / \mathrm{kg})$ and extra virgin olive oil $(93.1 \mu \mathrm{g} / \mathrm{kg})$. Palm, palmolein, corn, sunflower and soybean oils were found out of the limits recommended by the Commission Regulation (EU) 2020/1322, whereas, extra virgin olive oil, olive pomace oil and blend of $5 \%$ sunflower oil with extra virgin olive oil were in compliance and within the limits recommended by EU. Moreover, 3-MCPD content could be used as a good tool for authenticity and quality of genuine extra virgin olive oil.

\section{Conclusion}

3-MCPD as the emerging most toxic processing contaminant in refined edible oils was discussed. 3-MCPD forms during thermal processing of edible oils and it exerts carcinogenic or mutagenic effects on human and animal health. The data reported here provide new insights in relation to the processing contamination in edible oils and may stimulate further studies on the mitigation of these chemical contaminants.

\section{References}

1. Arisseto AP, Marcolino PFC, Augusti AC, Scaranelo GR, Berbari SAG, et al. (2017) Contamination of fried foods by 3 monochloropropane 1,2 diol Fatty acid esters during frying. J Am Oil Chem Soc 94(3): 449-455.

2. He D, Wei W, Guo Z (2020) Moderate Edible oil refining: state-of-the-art in China. J Am Oil Chem Soc 97(11): 1277-1279.

3. Ahn Y, Choi S, Kwak SY (2020) Remarkable effect of deprotonation on adsorption of 3-MCPD and glycidol on carboxylated Fe-MIL-88s. Journal of Environmental Chemical Engineering 8(6): 104456.

4. Liu X, Zhou S, Jiang Y, Xu X (2021) Optimization of deodorization design for four different kinds of vegetable oil in industrial trial to reduce thermal deterioration of product. J Am Oil Chem Soc 98(4): 475-483.

5. COC (2000) Annual report 2000. Committee on Carcinogenicity of Chemicals in Food, Consumer Products and the Environment.

6. European Commission (2001) Opinion of the Scientific Committee on Food on 3-Monochloro-propane-1,2-diol (3-MCPD), Updating the SCF Opinion of 1994. Scientific Committee on Food.

7. WHO (2007) Evaluation of certain food additives and contaminants (Sixty-seventh report of the Joint FAO/WHO Expert Committee on Food Additives). WHO Technical Report Series, No. 940 World Health 


\section{Open Access Journal of Microbiology \& Biotechnology}

Organisation.

8. WHO (2017) Evaluation of certain contaminants in food (Eighty-third report of the Joint FAO/WHO Expert Committee on Food Additives). WHO Technical Report Series, No. 1002, World health Organisation.

9. EFSA (2016) Risks for human health related to the presence of 3-and 2-monochloropropanediol (MCPD), and their fatty acid esters, and glycidyl fatty acid esters in food. EFSA Journal 14(5): e04426.

10. EFSA (2018) Update of the risk assessment on 3monochloropropane diol and its fatty acid esters. EFSA Journal 16(1): e05083.

11. IARC Monographs (2016) IARC Monographs on the Evaluation of Carcinogenic Risks to Humans, Some Chemicals Present in Industrial and Consumer Products, Food and Drinking-Water. International Agency for Research on Cancer, pp: 101.

12. Bergau N, Zhao Z, Abraham K, Monien BH (2021) Metabolites of 2- and 3-Monochloropropanediol (2- and 3-MCPD) in Humans: Urinary Excretion of 2-Chlorohydracrylic Acid and 3-Chlorolactic Acid after Controlled Exposure to a Single High Dose of Fatty Acid Esters of 2- and 3-MCPD. Mol Nutr Food Res 65(4).

13. Jędrkiewicz R, Kupska M, Głowacz A, Gromadzka J, Namieśnik J (2016) 3-MCPD: A Worldwide Problem of Food Chemistry. Crit Rev Food Sci Nutr 56(14): 22682277.

14. Kaze N, Watanabe Y, Sato H, Murota K, Kotaniguchi M, et al. (2016) Estimation of the Intestinal Absorption and Metabolism Behaviors of 2and 3 Monochloropropanediol Esters. Lipids 51(8): 913-922.

15. Peng X, Gan J, Wang Q, Shi Z, Xia X (2016) 3-Monochloro1,2-propanediol (3-MCPD) induces apoptosis via mitochondrial oxidative phosphorylation system impairment and the caspase cascade pathway. Toxicology 372: 1-11.

16. Zhong Y, Jin C, Wang X, Li X, Han J, et al. (2018) Protective effects of apigenin against 3-MCPD-induced renal injury in rat. Chemico-Biological Interactions 296: 9-17.

17. Araujo M, Beekman JK, Mapa MST, MacMahun S, Zhao $Y$, et al. (2020) Assessment of intestinal absorption/ metabolism of 3-chloro-1,2-propanediol (3-MCPD) and three 3-MCPD monoesters by Caco-2 cells. Toxicology in Vitro 67: 104887.

18. Huang G, Xue J, Sun X, Wang J, Yu LL (2018) Necroptosis in 3-chloro-1, 2-propanediol (3-MCPD)-dipalmitate- induced acute kidney injury in vivo and its repression by miR-223-3p. Toxicology 406-407: 33-43.

19. Liu PW, Li CI, Huang KC, Liu CS, Chen HL, et al. (2021) 3-MCPD and glycidol coexposure induces systemic toxicity and synergistic nephrotoxicity via NLRP3 inflammasome activation, necroptosis, and autophagic cell death. J Hazard Mater 405: 124241.

20. Huang G, Xue J, Sun X, Wang J, Wang Y, et al. (2018) Suppression of $\mathrm{T}$ lymphocyte activation by 3-chloro1,2-propanediol mono- and di-palmitate esters in vitro. Toxicology in Vitro 51: 54-62.

21. Ramy RE, Elhkim MO, Poul M, Forest MG, Leduque P, et al. (2006) Lack of effect on rat testicular organogenesis after in utero exposure to 3-monochloropropane-1,2diol (3-MCPD). Reprod Toxicol 22(3): 485-492.

22. Ramy RE, Elhkim MO, Lezmi S, Poul JM (2007) Evaluation of the genotoxic potential of 3-monochloropropane1,2-diol (3-MCPD) and its metabolites, glycidol and $\beta$-chlorolactic acid, using the single cell gel/comet assay. Food Chem Toxicol 45(1): 41-48.

23. Sawada S, Oberemm A, Buhrke T, Meckert C, Rozycki C, et al. (2015) Proteomic analysis of 3-MCPD and 3-MCPD dipalmitate toxicity in rat testis. Food Chem Toxicol 83: 84-92.

24. Lee BS, Park SJ, Kim YB, Han JS, Jeong EJ, et al. (2015) A 28day oral gavage toxicity study of 3-monochloropropane1,2-diol (3-MCPD) in CB6F1-non-Tg rasH2 mice. Food Chem Toxicol 86: 95-103.

25. Li J, Wang S, Wang M, Shi W, Du X, et al. (2013) The toxicity of 3-chloropropane-1,2-dipalmitate in Wistar rats and a metabonomics analysis of rat urine by ultra-performance liquid chromatography-mass spectrometry. Chem Biol Interact 206(2): 337-345.

26. Almoselhy RIM, Eid MM, Abd El Baset WS, Aboelhassan AFA (2021) Determination of 3-MCPD in some Edible Oils using GC-MS/MS. Egyptian J Chem 64(3): 16391652.

27. Almoselhy RIM (2021) A Review on Health risks from processing contaminants in edible oils and foodstuffs. International Journal of Advanced Technology \& Science Research 2(3): 143-161. 